\title{
MELANINS AND LIPIDS IN LYCOPERDON PERLATUM FRUIT BODIES
}

\author{
BY G. ALMENDROS \\ Instituto de Edafologia y Biologia Vegetal (C.S.I.C.), Serrano 115 apdo., 28006 Madrid, Spain \\ F. MARTÍN AND F. J. GONZÁLEZ-VILA \\ Instituto de Recursos Naturales y Agrobiologia (C.S.I.C.), Apdo. 1052, 41080 Sevilla, Spain
}

AND A. T. MARTÍNEZ

Centro de Investigaciones Biológicas (C.S.I.C.), Velázquez 144, 28006 Madrid, Spain

\begin{abstract}
After sequential degradation with sodium persulphate and potassium permanganate, the characteristics of the dark pigments from the soil gasteromycete Lycoperdon perlatum were described. Several aromatic acids (phenolic and benzenecarboxylic) were detected by glc-ms of the degradation products, but the aliphatic content of these polymer fractions was predominant, containing a high proportion of protein and showing fatty acids similar to those previously found in the lipid fraction. An acid soluble fraction of melanin, of a highly aliphatic nature, was also present in Lycoperdon fruit bodies.
\end{abstract}

The production of different types of metabolites by soil fungi has often been studied in relation to the development of soil organic matter. Amongst the large variety of components of the fungal biomass, certain organic compounds, such as the melanins and some lipid fractions, are relatively stable with regard to biological degradation, and tend to accumulate in soil humus (Martin \& Haider, 1971; Schnitzer \& Neyroud, 1975; Kumada \& Hurst, 1967; Martín, González-Vila \& Martin, 1983; Stevenson, 1966; Simoneit \& Mazurek, 1982).

Most of the studies on the composition and properties of fungal melanins have been carried out in Deuteromycetes, and the formation of this type of polymer by Gasteromycetes has received little attention (Wheeler, 1983; Bell \& Wheeler, 1986).

Melanization of the cell wall is a relatively common phenomenon in several species of soil fungi, but its biological significance and ultrastructural implications (Rast \& Hollenstein, 1977; Hegnauer, Nyhlen \& Rast, 1985) are only partially known. Due to the high carboxyl content of the fungal melanins, their dark colour, and their disorderly polymeric structure, several adaptive advantages of the pigmented fungi have been proposed. Protection against microbial attack, desiccation or ionizing radiations, transport of cations, detoxification, or mere accumulation of waste products, are some of the interpretations of melanin accumulation which are not mutually exclusive. This polymeric fraction often represents a major component of biomass during the final stages of fungal development.
The genus Lycoperdon Tourn., with more than 50 species (the common 'Puff-balls'), is one of the most representative members of the soil gasteromycetes. Among them, Lycoperdon perlatum Pers. is a cosmopolitan species, producing pigmented material in the fruit bodies. Mean values of the content of 25 mature carpophores recovered during this study showed $61 \%$ (oven-dry) of brown material (glebal tissue and spores) before dehiscence. Several organic analyses are shown in Table 1. The fraction of free lipids (extracted with light petroleum in a Soxhlet for $\mathbf{1 2} \mathrm{h}$ ) amounted to $2 \%$ of the total carbon of the studied sample $(1.5 \%$ of the oven-dry biomass). After lipid extraction, the melanin fractions were isolated by repeated treatments with $0 \cdot 1 \mathrm{~N}-\mathrm{NaOH}$ under nitrogen, including ultrasonic disruption. Alkali-extractable melanins were not very abundant, and most of the melanin remained in stable association with the hyphae and spores: $19 \%$ of the total carbon of the sample was extracted after five alkaline treatments. Upon acidification of the extract with $\mathrm{HCl}$ (at $\mathrm{pH}$ 1.5 ), an insoluble alkali-melanin was recovered by precipitation, amounting to $7 \%$ of the total carbon. It was purified by centrifugation at $30000 \mathrm{~g}$ in alkaline $\mathrm{pH}$, then reprecipitated and dialysed. A soluble fraction was also recovered from the yellowish, acid-soluble material of the original alkaline extract, by means of adsorption chromatography using insoluble polyvinylpyrrolidone, as described for soil fulvic acids (Lowe, 1975). After removing the substances not adsorbed on the resin with water, the coloured, acid-soluble fraction was 
Table 1. Analytical characteristics of Lycoperdon perlatum (gleba + spores)

\begin{tabular}{|c|c|c|c|c|c|c|c|c|}
\hline \multicolumn{5}{|c|}{ Elementary composition (ashfree) } & \multirow[b]{2}{*}{ Lipids } & \multirow{2}{*}{$\begin{array}{l}\mathrm{NaOH} \text { soluble } \\
\text { acid insoluble } \\
\text { (melanin) }\end{array}$} & \multirow{2}{*}{$\begin{array}{l}\text { Acid and } \\
\text { alkali } \\
\text { soluble }\end{array}$} & \multirow{2}{*}{$\begin{array}{c}\text { Alkali } \\
\text { insoluble } \\
\text { (residue) }\end{array}$} \\
\hline $\mathrm{C}$ & $\mathrm{H}$ & 0 & $\mathbf{N}$ & $\mathrm{C} / \mathrm{N}$ & & & & \\
\hline $55^{\circ} 94$ & 5.85 & $29 \cdot 80$ & $8 \cdot 41$ & $6 \cdot 65$ & $\begin{array}{l}1.04^{\star} \\
1.90 \dagger\end{array}$ & $\begin{array}{l}3.67^{\star} \\
6.69 \dagger\end{array}$ & $\begin{array}{r}6.53^{\star} \\
11.92 \dagger\end{array}$ & $\begin{array}{l}43.59^{\star} \\
79.50 \dagger\end{array}$ \\
\hline
\end{tabular}

Table 2. Analytical characteristics of the fractions isolated from Lycoperdon perlatum

\begin{tabular}{|c|c|c|c|c|c|c|c|}
\hline \multirow[b]{2}{*}{ Sample } & \multicolumn{4}{|c|}{ Elementary composition ${ }^{\star}$} & \multirow{2}{*}{$\frac{\begin{array}{c}\text { Atomic } \\
\text { ratios }\end{array}}{\mathrm{H} / \mathrm{C} \mathrm{O} / \mathrm{C}}$} & \multirow{2}{*}{$\begin{array}{c}\text { Hydrolyzable } \\
\text { by } \mathrm{K}_{2} \mathrm{~S}_{2} \mathrm{O}_{8}(\%)\end{array}$} & \multirow{2}{*}{$\begin{array}{c}\text { Hydrolyzable } \\
\text { N }(\%)\end{array}$} \\
\hline & C & $\mathrm{H}$ & $\mathrm{O}$ & $\mathbf{N}$ & & & \\
\hline Total melanin & 53.85 & $4 \cdot 87$ & $32 \cdot 83$ & 8.44 & 1.090 .46 & $35 \cdot 80$ & 50.83 \\
\hline Non-degradablet melanin & $52 \cdot 70$ & $3 \cdot 80$ & 36.85 & 6.65 & 0.870 .52 & - & - \\
\hline Acid-soluble fraction & $49 \cdot 02$ & $3 \cdot 18$ & $43 \cdot 54$ & 4.26 & $0.78 \quad 0.67$ & $77 \cdot 28$ & $84 \cdot 91$ \\
\hline $\begin{array}{l}\text { Non-degradablet acid-soluble } \\
\text { fraction }\end{array}$ & 40.68 & $2 \cdot 57$ & 53.92 & $2 \cdot 83$ & 0.760 .99 & - & - \\
\hline
\end{tabular}

recovered by elution with $0.1 \mathrm{~N}-\mathrm{NaOH}$ and chromatographed through Amberlite IR-120- $\mathrm{H}^{+}$ to remove $\mathrm{Na}^{+}$.

The elementary composition of melanins was determined with a Hewlett-Packard CHN 185 microanalyzer (Table 2). Atomic $\mathrm{H} / \mathrm{C}$ and $\mathrm{O} / \mathrm{C}$ ratios of melanin are similar to those reported for melanins of Deuteromycetes (Schnitzer, Ortiz de Serra \& Ivarson, 1973), and the nitrogen content was relatively high. More than half of this $N$ probably consists of protein-like material associated or co-extracted together with the melanin. A considerable proportion of these materials can be split off using a mild reagent such as potassium persulphate, which degraded $38 \%$ of the total polymer, i.e. a similar value to those described for other types of melanins by Martín et al. (1983). The acid-soluble fraction is different from a typical melanin, showing low resistance to persulphate attack and a reduced proportion of non-hydrolyzable nitrogen.

Infrared spectra gave no definitive structural information. Aromatic groups (near $1510 \mathrm{~cm}^{-1}$ ) were evident, but intense amide bands (1650, $1540 \mathrm{~cm}^{-1}$ ) were present. Carboxyl absorption near $1720 \mathrm{~cm}^{-1}$ was not very pronounced, and aliphatic vibrations $\left(2920,1460 \mathrm{~cm}^{-1}\right.$ ) were also detected. After persulphate treatment (mild degradation removing the less strongly associated polymer components), the amide bands tend to disappear, and the aromatic and carboxyl bands become more conspicuous.
Spectroscopic parameters of the melanin in the visible range were determined in solutions of 136 p.p.m. C (Kononova, 1961). The extinction value at $465 \mathrm{~nm}(1.25)$ and the ratio between extinctions at 465 and $665 \mathrm{~nm}(3 \cdot 2)$ were typical of this type of substance. The second parameter is considered mainly to be influenced by particle size (Chen, Senesi \& Schnitzer, 1977) and agrees with the results of gel filtration when using Sephadex G-50, which showed a molecular size distribution consisting of an excluded fraction $\left(K_{\mathrm{av}}=0\right.$, representing $26 \%$ ), a small fraction of $K_{\mathrm{av}}=0.6(16 \%)$ and a low molecular size fraction $\left(K_{\mathrm{av}}=1.03\right.$; $58 \%$ ). Considering the molecular weight limits of the gel used $\left(>10^{4}\right.$ for $K_{\mathrm{av}}=0$ and $<5 \times 10^{2}$ for $K_{\mathrm{av}}=1$ ), it may be considered that an important proportion of the acid-insoluble melanin of $L$. perlatum is of relatively small molecular size.

The experimental conditions for melanin degradation and glc-ms studies have been reported previously (Martín, Saiz-Jiménez \& GonzálezVila, 1981; Martín et al., 1983; Matsuda \& Schnitzer, 1972; Almendros et al., 1985). After exhaustive lipid extraction, the acid-insoluble melanin was degraded with potassium persulphate, and the non-degraded residue was methylated and oxidized with potassium permanganate.

The composition of the lipid fractions of $L$. perlatum was similar to that found in soil microfungi (Mumma, Fergus \& Sekura, 1970; Mumma, Sekura \& Fergus, 1971; Gunasekaran \& Weber, 1972 ; Wassef, 1977; Weete, 1976, 1980). The fatty 

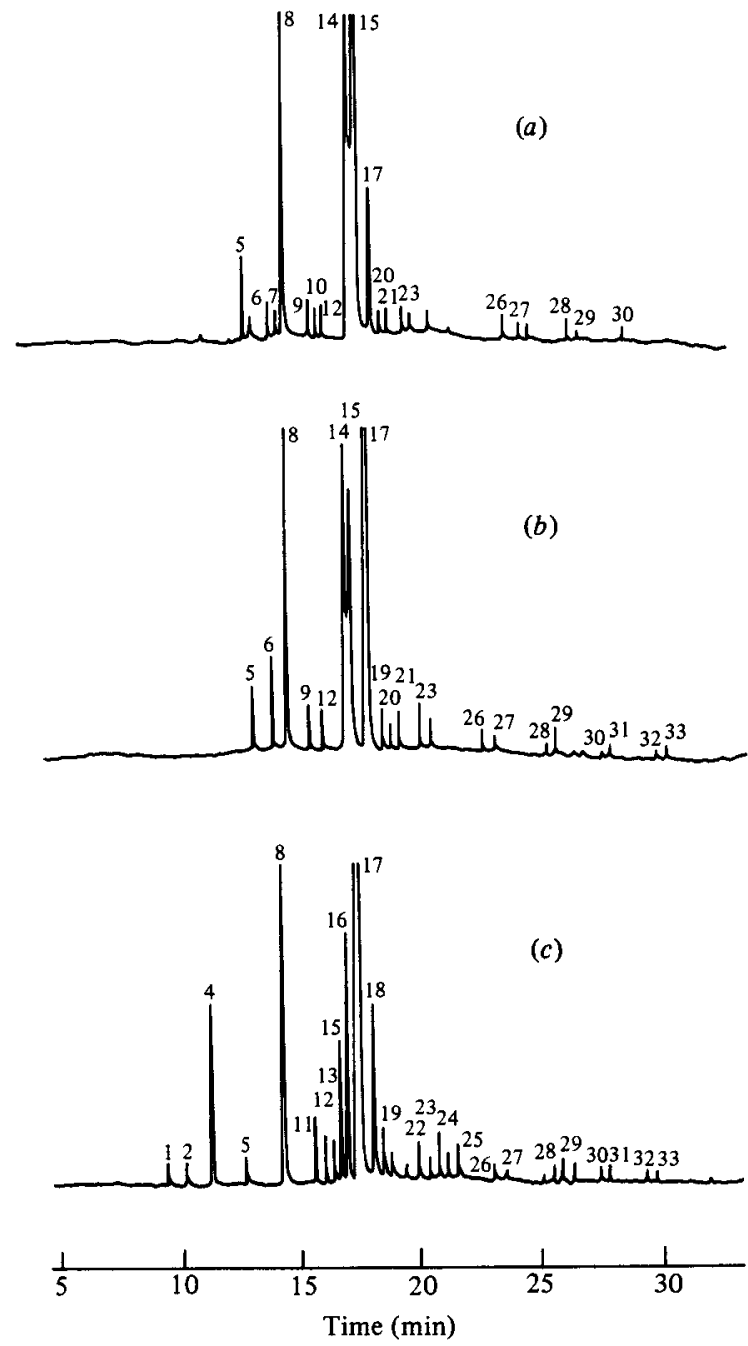

Fig. 1. Gas chromatographic separation of the free lipid fraction (a), and the oxidation products obtained after persulphate degradation (b), followed by alkaline permanganate oxidation (c), of Lycoperdon perlatum melanin (Peak numbers refer to Table 3 ).

acid fraction was predominantly constituted by the $\mathrm{C}_{16}$ and $\mathrm{C}_{18}$ chains (Fig. 1a). The sum of the $\mathrm{C}_{18}$ unsaturated fatty acids represented more than half of the total lipid fraction. Palmitic acid was the most abundant saturated fatty acid, but palmitoleic, stearic and myristic acids were also present. The proportion of other homologues in the $\mathrm{C}_{14}-\mathrm{C}_{23}$ range was hardly significant, and the alkanes (in the $\mathrm{C}_{19}-\mathrm{C}_{27}$ range) amounted to a very small proportion of the lipid extract, and a predominance of high molecular weight homologues $\left(>\mathrm{C}_{20}\right.$ ) was found. Although this latter characteristic has been frequently considered as typical of cuticular lipids of higher plants, it has also been reported in microbial lipids (Weete et al., 1969). On the other hand, the alkane series showed no strong predominance of the odd-C number homologues, as described in several microbial species, in contrast with those formed by vascular plants. Consequently, the alkane series is independent of that of fatty acids, and the origin of these alkanes may not simply be a mere decarboxylation of fatty acids (Oró et al., 1967). This phenomenon seems to be characteristic of certain microbial taxa and has been reported in several bacterial and fungal lipids (Weete, 1972; Fisher, Holloway \& Richmond, 1972).

The above-mentioned fatty chains were the most abundant compounds obtained after persulphate degradation of the melanin (Fig. 1b), suggesting that they are also bound to or entrapped in the polymer (Rast \& Hollenstein, 1977). The saturated chains were more abundant than the unsaturated ones, but there were also substantial amounts of $\mathrm{C}_{18: 1}, \mathrm{C}_{18: 2}$ and $\mathrm{C}_{16: 1}$ acids. The proportion of alkanes was reduced (a predominance of the homologues of more than $\mathrm{C}_{20}$ is observed again) and no aromatic compounds were detected. The predominance of aliphatic chains in this persulphate-removable material is typical of fungal melanins (Martín et al., 1983).

After permanganate degradation, a considerable proportion of aromatic compounds was obtained (Table 3), the most abundant being the 1,2,4,5benzenetetracarboxylic and the 1,2,3-benzenetricarboxylic acids (compounds 16 and 4). Benzenedicarboxylic acids ( 1 and 2 ), and the 1,2,3,5benzenetetracarboxylic acid (18) were also present. Phenolic acids were only represented by a methoxy benzenetricarboxylic acid (11) and a dimethoxy benzenetricarboxylic acid (13). The small proportion of phenolic acids agrees with data reported by Schnitzer et al. (1973) in fungal humic acid-like polymers. The absence of dicarboxylic aliphatic acids is noticeable, as well as the predominance of aliphatic chains, previously detected as free forms, but in this bound material the relative proportion of the unsaturated chains was comparatively lower.

The results of these degradation studies suggest that the Lycoperdon melanin is a heteropolymer with a relatively high aromatic content (nearly $33 \%$ of the products in the persulphate-boiled melanin fraction), and a significant aliphatic fraction consisting essentially of the same fatty compounds found in the free forms. The main difference is due to the remarkable tendency of unsaturated chains to be present in the free or loosely bound forms. 
Table 3. Organic compounds (as metipl esters) identified by GC-MS in the lipid and melanin fractions of Lycoperdon perlatum

\begin{tabular}{|c|c|c|c|c|}
\hline & \multirow[b]{2}{*}{ Peak compound } & \multirow[b]{2}{*}{ FL } & \multicolumn{2}{|c|}{ Melanin ${ }^{\star}$} \\
\hline & & & S & $\mathbf{M}$ \\
\hline (1) & 1,2-Benzenecarboxylic acid dimethyl ester & - & - & + \\
\hline (2) & 1,3-Benzenedicarboxylic acid dimethyl ester & - & - & + \\
\hline (3) & Methyl tetradecanoate & + & - & - \\
\hline (4) & 1,2,3-Benzenetricarboxylic acid trimethyl ester & - & - & ++ \\
\hline$(5)$ & Methyl pentadecanoate & - & ++ & + \\
\hline (6) & Methyl hexadecenoate & + & + & - \\
\hline$(7)$ & n-Nonadecane & + & - & - \\
\hline$(8)$ & Methyl hexadecanoate & ++ & ++ & ++ \\
\hline (9) & 17-C branched fatty acid methyl ester & + & + & - \\
\hline (10) & n-Eicosane & + & - & - \\
\hline (11) & Methoxy benzenetricarboxylic acid trimethyl ester & - & - & + \\
\hline (12) & Methyl heptadecanoate & + & + & + \\
\hline (13) & Dimethoxy benzenetricarboxylic acid trimethyl ester & - & - & + \\
\hline (14) & Methyl octadecadienoate & ++ & ++ & - \\
\hline (15) & Methyl octadecenoate & ++ & ++ & + \\
\hline (16) & 1,2,4,5-Benzenetetracarboxylic acid tetr:nethyl ester & - & - & ++ \\
\hline (17) & Methyl octadecenoate & ++ & ++ & ++ \\
\hline (18) & $1,2,3,5$-Benzenetetracarboxylic acid tetramethyl ester & - & - & ++ \\
\hline (19) & 19-C Branched fatty acid methyl ester & - & + & - \\
\hline (20) & n-Docosane & + & + & - \\
\hline (21) & Methyl nonadecanoate & + & - & + \\
\hline (22) & n-Tricosane & - & - & + \\
\hline (23) & Methyl eicosanoate & + & + & + \\
\hline (24) & $\mathrm{n}$-Tetracosane & - & - & + \\
\hline (25) & Methyl eneicosanoate & - & - & + \\
\hline (26) & $\mathrm{n}$-Pentacosane & + & + & - \\
\hline (27) & Methyl docosanoate & + & - & + \\
\hline (28) & n-Hexacosane & + & + & - \\
\hline (29) & Methyl tricosanoate & + & - & + \\
\hline (30) & n-Heptacosane & + & + & + \\
\hline (31) & Methyl tetracosanoate & - & + & + \\
\hline (32) & n-Octacosane & - & + & + \\
\hline (33) & Methyl pentacosanoate & - & + & + \\
\hline
\end{tabular}

FL: free lipids. *Degradation methods: $S=$ acid persulphate degradation, $M=$ alkaline permanganate oxidation. Compound abundance: + , present $(0.1-3 \%$ of total volatile products); ++ , abundant $(>3 \%$ of total volatile products).

The degradation products of the acid-soluble fraction of the alkaline extract essentially corresponded to the same compounds reported in acidinsoluble melanin, but with a higher predominance of aliphatic products.

The results obtained suggest the presence in Lycoperdon fruit bodies of a significant proportion of a melanin with a simpler composition than those of soil microfungi (Schnitzer et al., 1973). On the other hand, the polar lipid fraction of Lycoperdon, mainly consisting of fatty acids of relatively shortlength chains $\left(<\mathrm{C}_{20}\right)$ with a predominantly unsaturated nature, may be considered easily degradable in the soil (Simoneit \& Mazurek, 1982).

\section{REFERENCES}

Almendros, G., Martínez, A. T., Martín, F. \& GonZÁlez-VILA, F. J. (1985). Degradative oxidation products of the melanin of Ulocladium atrum. Soil Biology and Biochemistry 17, 723-726.

Bell, A. A. \& WheELer, M. H. (1986). Biosynthesis and functions of fungal melanins. Annual Review of Phytopathology 24, 411-451.

Chen,, Y., Senesi, N. \& Schnitzer, M. (1977). Information provided on humic substances by $\mathrm{E}_{4} / \mathrm{E}_{6}$ ratios. Soil Science Society of America. Fournal 41, 352-358.

Fisher, D. J., Holloway, P. J. \& Richmond, D. V. (1972). Fatty acid and hydrocarbon constituents of the surface and wall lipids of some fungal spores. Fournal of General Microbiology 72, 71-78. 
Gunaseraran, M. \& Weber, D. J. (1972). Polar lipids and fatty acid composition of phytopathogenic fungi. Phytochemistry II, 3367-3369.

Hegnauer, H., Nyhlen, L. \& Rast D. M. (1985). Ultrastructure of native and synthetic Agaricus bisporus melanins - Implications as to the compartmentation of melanogenesis in fungi. Experimental Mycology 9, 221-229.

Kononova, M. (1961). Soil Organic Matter. Pergamon Press : London.

Kumada, K. \& Hurst, M. (1967). Green humic acid and its possible origin as a fungal metabolite. Nature, London 214, 631-633.

LowE, L. E. (1975). Fractionation of acid-soluble components of soil organic matter using polyvinyl pyrrolidone. Canadian fournal of Soil Science 55, 119-126.

Martín, F., González-Vila, F. J. \& Martin, J. P. (1983). The persulfate oxidation of fungal melanins. Soil Science Society of America. Fournal 47, 11451148.

Martín, F., Saiz-Jiménez, C. \& GonzÁlez-Vila, F. J. (1981). The persulfate oxidation of a soil humic acid. Soil Science 132, 200-203.

MarTin, J. P. \& Haider, K. (1971). Microbial activity in relation to soil humus formation. Soil Science III, 54 63.

Matsuda, K. \& Schnitzer, M. (1972). The permanganate oxidation of humic acids extracted from acid soils. Soil Science 114, 185-193.

Mumma, R. O., Fergus, C. L. \& Sekura, R. D. (1970). The lipids of thermophilic fungi: lipid composition. Comparisons between thermophilic and mesophilic fungi. Lipids 5, 100-103.

Mumma, R. O., Sekura, R. D. \& Fergus, C. L. (1971). Thermophilic fungi. II. Fatty acid composition of polar and neutral lipids of thermophilic and mesophilic fungi. Lipids 6, 584-588.

Oró, J., Tornabene, T. G., Nooner, D. W. \& Gelpi, E.
(1967). Aliphatic hydrocarbons and fatty acids of some marine and freshwater microorganisms. Fournal of Bacteriology 93, 1811-1818.

Rast, D. \& Hollenstein, G. O. (1977). Architecture of the Agaricus bisporus spore wall. Canadian fournal of Botany 55, 2251-2262.

SchNitzer, M. \& NeYroud, J. A. (1975). Further investigations on the chemistry of fungal 'humic acids'. Soil Biology and Biochemistry 7, 365-371.

Schnitzer, M., Ortiz de Serra, M. I. \& Ivarson, K. (1973). The chemistry of fungal humic acid-like polymers and of soil humic acids. Soil Science Society of America. Proceedings 37, 229-236.

Simoneit, B. R. T. \& MAZUREK, M. A. (1982). Organic matter of the troposphere. II. Natural background of biogenic lipid matter in aerosols over the rural western United States. Atmospheric Environment 16, 21392159.

SteVEnson, F. J. (1966). Lipids in soil. Fournal of the American Oil Chemists' Society 43, 203-210.

WASSEF, M. K. (1977). Fungal lipids. Advances in Lipid Research 15, 159-232.

WEETE, J. D. (1972). Aliphatic hydrocarbons of the fungi. Phytochemistry 11, 1201-1205.

WeETE, J. D. (1976). Algal and fungal waxes. In Chemistry and Biochemistry of Natural Waxes (ed. P. E. Kolattukudy), pp. 349-418. Amsterdam: Elsevier.

WeETE, J. D. (1980). Lipid Biochemistry of Fungi and other Organisms. New York and London: Plenum Press.

Weete, J. D., Laseter, J. L., Weber, D. J., Hess, W. M. \& STOCKS, D. L. (1969). Hydrocarbons, fatty acids and ultrastructure of smut spores. Phytopathology 59, 545548.

WHEELER, M. H. (1983). Comparisons of fungal melanin biosynthesis in ascomycetous, imperfect and basidiomycetous fungi. Transactions of the British Mycological Society 8r, 29-36.

(Received for publication 8 fanuary 1987 ) 